\title{
The Difference in Incidence of Scabies between Conventional and Modern Boarding School
}

\author{
Perbedaan Angka Kejadian Scabies antara Pondok Pesantren Konvensional \\ dan Pondok Pesantren Modern
}

\author{
Kanti Ratnaningrum ${ }^{1, *}$, Amanatun Avidah ${ }^{2}$ \\ ${ }^{1}$ Basic Clinical Science Department, Medical Faculty, Universitas Muhammadiyah Semarang, Jalan Kedungmundu No.18, \\ Kedungmundu, Tembalang, Semarang City, Central Java, Indonesia. \\ ${ }^{2}$ Medical Faculty, Universitas Muhammadiyah Semarang, Jalan Kedungmundu No.18, Kedungmundu, Tembalang, \\ Semarang City, Central Java, Indonesia.
}

DATA OF ARTICLE:

Received: 15 Oct 2019

Reviewed: 27 Nov 2019

Revised: 3 Des 2019

Accepted: 5 Jan 2020

*CORRESPONDENCE:

kantiratna@unimus.ac.id

DOI:

$10.18196 / \mathrm{mm} .200141$

TYPE OF ARTICLE: Research

\begin{abstract}
The prevalence of scabies in children is still high in Indonesia, especially in children who live in dormitories such as Islamic boarding schools. Rise of modern boarding school that is claimed to be better than conventional boarding school makes researchers moved to find out whether there are differences in the occurrence of scabies in conventional boarding school and modern boarding school. This study is a descriptive observational study. The sample used was 95 respondents in each boarding schools that obtained by a simple random sampling technique. Research data were collected in the form of questionnaires and examination of the diagnosis of scabies using a dermoscope. The data was analyzed using data tabulation. From 190 respondents, most of the samples were in the age range of $14-16$ years $(46.8 \%)$. Scabies occurred in conventional boarding school were $35.3 \%$ (46 respondents), and $9.8 \%$ (5 respondents) occurred in modern boarding school. It can be concluded that the occurrence of scabies in modern boarding school is less than in conventional boarding school.
\end{abstract}

Keywords: Scabies; Boarding school; Conventional; Modern

\begin{abstract}
Abstrak: Prevalensi skabies pada anak-anak masih tinggi di Indonesia, terutama pada anak-anak yang tinggal di asrama seperti pondok pesantren. Bangkitnya pondok pesantren modern yang diklaim lebih baik dari pesantren konvensional membuat peneliti tergerak untuk mengetahui apakah ada perbedaan dalam terjadinya skabies di pondok pesantren konvensional dan pesantren modern. Penelitian ini adalah penelitian observasional deskriptif. Sampel yang digunakan adalah 95 responden di setiap pesantren yang diperoleh dengan teknik simple random sampling. Data penelitian dikumpulkan dalam bentuk kuesioner dan pemeriksaan diagnosis skabies menggunakan dermoscope. Data dianalisis menggunakan tabulasi data. Dari 190 responden, sebagian besar sampel berada dalam kisaran usia 14-16 tahun (46,8\%). Skabies yang terjadi di pesantren konvensional sebanyak 35,3\% (46 responden), dan 9,8\% (5 responden) terjadi di pesantren modern. Dapat disimpulkan bahwa angka kejadian scabies di pondok pesantren modern lebih sedikit dibanding dengan pondok pesantren konvensional.
\end{abstract}

Kata Kunci: Skabies; Pesantren; Konvensional; Modern 


\section{INTRODUCTION}

Scabies is a disease caused by arthropod parasitic infection, Sarcoptes scabiei var hominis. Diagnosis of Scabies is confirmed by the discovery of Sarcoptes scabei mites and is usually accompanied by symptoms of itching at night, and there are tunnels in predilection sites. ${ }^{2}$ Scabies are usually found in residential areas such as in boarding school. 3 The prevalence of scabies in boarding school at $43 \% ; 36.3 \% ; 51.6 \% .^{4-6}$

Boarding school as private Islamic religious education institutions with a boarding system.? boarding school categories based on characteristics and traditions are conventional boarding school and modern boarding school. ${ }^{8}$ Conventional boarding schools or also called salaf / traditional are places for studying Islamic religion without including public education in them, whereas modern boarding schools are places for studying a combination of religious knowledge and general science. ${ }^{7-9}$ In addition to religious studies, modern Islamic boarding school apply the curriculum set by the Ministry of Religion or Ministry of Education and Culture. ${ }^{7}$ some previous studies only discussed scabies in 1 Islamic boarding school such as Saad, Khotimah, and Ratnasari, studies; minimal information about the category of Islamic boarding school that was used as the location of the study; as well as the rise of modern boarding schools which are claimed to be better than conventional boarding schools make researchers moved to find out whether there are differences occurrence of scabies in conventional boarding school and modern boarding school.4-6

\section{MATERIALS AND METHOD}

This study is a descriptive observational study, with 95 samples in each study place, a conventional boarding school, and a modern boarding school. The sample obtained using the simple random sampling technique with a numbering system. The research used primary data by examination of scabies diagnosis using a dermoscope. The study conducted at conventional boarding school Wasilatul Huda, Kendal, and modern boarding school Selamat, Kendal, Central Java in March-April 2019 with the inclusion criteria of students who are living in boarding school. Data analysis using data tabulation. The study has received ethical approval from the Health Research Ethics Committee (KEPK) Medical Faculty, Universitas Muhammadiyah Semarang No.029 / EC / FK / 2019.
RESULT

Table 1. Characteristics of boarding school students

\begin{tabular}{ll}
\hline Characteristics of samples & $\mathbf{N}(\%)$ \\
\hline Age & \\
$11-13$ yo & $36(18.9)$ \\
$14-16$ yo & $89(46.8)$ \\
$>17$ yo & $65(34.2)$ \\
\hline Scabies & \\
Scabies & $51(26.8)$ \\
No scabies & $139(73.2)$ \\
\hline
\end{tabular}

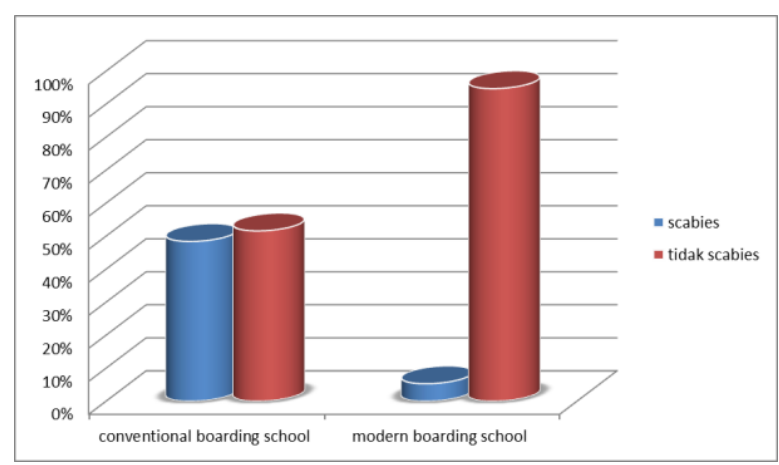

Figure 1. Graph of differences occurrence of scabies in both of boarding school

The study was conducted with 190 samples which consist of 95 samples in each conventional and modern boarding school students in a ratio of 1:1. The distribution of sample characteristics can be seen in Table 1. Table 1 shown most of the samples in the age range of $14-16$ years (46.8\%) and 51 samples (26.8\%) were scabies. From Figure 1, it can be seen that 46 samples scabies (48.4\%) from the conventional boarding school and 49 samples do not scabies (51.6\%). In modern boarding school, only a small proportion of samples who scabies in 5 samples (5.3\%) and most of the samples did not scabies in 5 people (94.7\%).

\section{DISCUSSION}

Range of 14-16 years old is most age samples occurrence scabies. These results are similar to previous studies. ${ }^{9,10}$ Range of 11-15 years old most occurrence of scabies (76.9\%). ${ }^{10}$ The results of this study are slightly different from other studies, which mention 17-25 years old is the most commonly found scabies. ${ }^{11}$ Age is a risk factor for scabies that has an influence on the hygiene of the scabies patients. ${ }^{9}$ Age influences capture and thought patterns. As you get older, you will also develop your catching power and mindset so that your knowledge is better. Previous exposure experiences were very instrumental in students mindset. ${ }^{12,13}$ 
The occurrence of scabies in the conventional boarding school is higher than in the modern boarding school. Ihtiaringtyas et al. (2019), ${ }^{10}$ stated that scabies is a common disease in boarding school and often occurs in boarding schools. This reasonableness attitude can be due to the stigma that was circulating among students and teachers of conventional Islamic boarding schools that " if not yet experienced scabies, not a boarding school students." It has caused the omission of scabies mass conditions in a conventional boarding school environment, and no effort was made by the management of the boarding school to prevent disease expansion or comprehensive management so that scabies did not repeatedly occur of students.

Less knowledge and behavior in the prevention of scabies have a significant relationship to ${ }^{4,14,15}$, but other studies have different results. the level of knowledge was not related to the occurrence of scabies. ${ }^{16,17}$ Several factors that can increase the risk of scabies include age, skin hygiene, hand hygiene, towel cleanliness, clothing cleanliness, and cleanliness of beds. ${ }^{16}$ Some differences in habits/ lifestyles/ activities contribute to the occurrence of scabies so natural if more scabies found in conventional boarding school students.

\section{CONCLUSION}

There is a difference between the occurrence of scabies in conventional boarding schools and a modern boarding school. The occurrence of scabies is higher in conventional boarding schools than in a modern boarding school.

\section{REFERENCES}

1. Siregar, R. S. Atlas Berwarna Saripati Penyakit Kulit: Kandidiasis. Jakarta: EGC. 2005; 45-9.

2. Djuanda, A. Ilmu Penyakit Kulit Dan Kelamin Fakultas Kedokteran Universitas Indonesia. Jakarta: Universitas Indonesia. 2007.

3. Soemirat, J. Kesehatan lingkungan. Yogyakarta: Gadjah Mada University Press. 2011.

4. Saad, S. Pengaruh Faktor Higiene Perorangan terhadap Angka Kejadian Skabies di Pondok Pesantren AnNajach Magelang (Doctoral dissertation, Faculty of Medicine). 2008.

5. Avidah, A., Krisnarto, E., \& Ratnaningrum, K. Faktor Risiko Skabies di Pondok Pesantren Konvensional dan Modern. Herb-Medicine Journal, 2019, 2(2), 58-63.

6. Ratnasari, A. F., \& Sungkar, S. Prevalensi Skabies dan Faktor-faktor yang Berhubungan di Pesantren $\mathrm{X}$, Jakarta Timur. eJournal Kedokteran Indonesia. 2014, 2(1), 7-12.

7. Hasyim, H. Transformasi Pendidikan Islam (Konteks Pendidikan Pondok Pesantren). Jurnal Pendidikan Agama Islam-Ta'lim, 2015, 13(1), 57-77.

8. Muhakamurrohman, A. Pesantren: Santri, kiai, dan tradisi. IBDA: Jurnal Kajian Islam Dan Budaya, 2014, 12(2), 109-118.

9. Dhofir, Z. Tradisi Pesantren Ditinjau dari Tradisi Kyai. Yogyakarta: Kanisus. 1983.

10. Ihtiaringtyas, S., Mulyaningsih, B., \& Umniyati, S. R. Faktor Risiko Penularan Penyakit Skabies pada Santri di Pondok Pesantren An Nawawi Berjan Kecamatan Gebang Kabupaten Purworejo Jawa Tengah. Balaba: Jurnal Litbang Pengendalian Penyakit Bersumber Binatang Banjarnegara, 2019, 15(1), 83. 90.

11. Gustia, R., \& Anas, E. Faktor-faktor yang Berhubungan dengan Kejadian Skabies di Wilayah Kerja Puskesmas Lubuk Buaya Kota Padang Tahun 2015. Jurnal Kesehatan Andalas, 2018, 7(1), 51-58.

12. Muslih, R., Korneliani, K., \& Novianti, S. Hubungan Personal Hygiene dengan Kejadian Skabies pada Santri di Pondok Pesantren Cipasung Kabupaten Tasikmalaya. Tasikmlaya: Universitas Siliwangi. 2012.

13. Ibadurrahmi, H., Veronica, S., \& Nugrohowati, N. Faktor-faktor yang berpengaruh terhadap kejadian penyakit skabies pada santri di Pondok Pesantren Qotrun Nada Cipayung Depok Februari tahun 2016. Jurnal Profesi Medika: Jurnal Kedokteran dan Kesehatan, 2017, 10(1), 33-45.

14. Nur Rohmawati, R. Hubungan antara faktor pengetahuan dan perilaku dengan kejadian skabies di Pondok Pesantren Al-Muayyad Surakarta (Doctoral dissertation, Universitas Muhammadiyah Surakarta). 2010.

15. Rianti, E., \& Triwinarto, A. Efforts to Improve Management of Student Health Services at Islamic Boarding Schools in Indonesia. In 4th International Symposium on Health Research (ISHR 2019) (pp. 475 477). Atlantis Press. 2020.

16. Avidah, A., Krisnarto, E., \& Ratnaningrum, K. Faktor Risiko Skabies di Pondok Pesantren Konvensional dan Modern. Herb-Medicine Journal, 2019, 2(2), 58-63.

17. Arifuddin, A., Kurniawan, H., \& Fitriani, F. Faktor Risiko Kejadian Scabies di Rumah Sakit Umum Anutapura Palu (Risk Factors Scabies at General Hospital Anutapura Palu). Medika Tadulako: Jurnal Ilmiah Kedokteran Fakultas Kedokteran dan Ilmu Kesehatan, 2016, 3(3), 40-59. 